\title{
Microscopic fungi isolated from the Domica Cave system (Slovak Karst National Park, Slovakia). A review
}

\author{
Alena Nováková ${ }^{1}$
}

\begin{abstract}
:
Novakova A. 2009. Microscopic fungi isolated from the Domica Cave system (Slovak Karst National Park, Slovakia). A review. International Journal of Speleology, 38 (1), 71-82. Bologna (Italy). ISSN 0392-6672.

A broad spectrum, total of 195 microfungal taxa, were isolated from various cave substrates (cave air, cave sediments, bat droppings and/or guano, earthworm casts, isopods and diplopods faeces, mammalian dung, cadavers, vermiculations, insect bodies, plant material, etc.) from the cave system of the Domica Cave (Slovak Karst National Park, Slovakia) using dilution, direct and gravity settling culture plate methods and several isolation media. Penicillium glandicola, Trichoderma polysporum, Oidiodendron cerealis, Mucor spp., Talaromyces flavus and species of the genus Doratomyces were isolated frequently during our study. Estimated microfungal species diversity was compared with literature records from the same substrates published in the past.
\end{abstract}

Keywords: Domica Cave system, microfungi, air, sediments, bat guano, invertebrate traces, dung, vermiculations, cadavers

Received 29 April 2008; Revised 15 September 2008; Accepted 15 September 2008

\section{INTRODUCTION}

Microscopic fungi are an important part of cave microflora and occur in various substrates in caves, such as cave sediments, vermiculations, bat droppings and/or guano, decaying organic material, etc. Their widespread distribution contributes to their important role in the feeding strategies of cave fauna.

A study of microscopic fungi in the Domica Cave System (Slovak Karst National Park, Slovakia) was started in 2002 within the frame of the project studying cave microflora and fauna and their feeding preferences and it was subsequently carried out each spring and autumn. The first isolation was performed only on the Domica Cave (a show cave). Later, parts not open to the public were sampled as well, i.e. the chasm-like Čertova diera Cave, the Dlhá Chodba Cave and its part in Hungary with the aim to obtain a broad spectrum of microscopic fungi which can represent potential food for cave mycophagous invertebrates. Partial results of these samplings were presented at international conferences and workshops or published in scientific journals (Nováková, 2004a, b, 2005, 2006, 2008, Elhottová et al., 2003, 2004, Nováková et al., 2005, 2008, Lukešová \& Nováková, 2008, Šustr et al., 2005).

The goal of this paper is to form a view of microscopic fungi isolated from different substrates and parts of the Domica Cave system and a comparison of

1 Biology Centre, AS CR, v.v.i., Institute of Soil Biology, Na Sádkách 7, CZ-370 05 České Budějovice, Czech Republic,

E-mail address: alena@upb.cas.cz the obtained microfungal spectrum with records of previously published data from the Baradla Cave and other caves in the world.

\section{DESCRIPTION OF STUDIED CAVES}

The Domica Cave system is located on the southwestern edge of the Silická Plateau in the Slovak Karst National Park, close to the state border with Hungary. Geographic coordinates of the Domica Cave entrance are $48^{\circ} 28^{\circ} 43^{\prime \prime} \mathrm{N}$ and $20^{\circ} 28^{\prime} 22^{\prime \prime} \mathrm{E}$, and its entrance is counted in the land-register of the village Kečovo $10 \mathrm{~km}$ south of the town Plešivec, at the southern foothill of Domica Hill, $339 \mathrm{~m}$ a.s.1. The Domica Cave is connected with the chasm-like Čertova diera Cave (the Devil's Pit Cave) and together with the Stará Domica Cave (the Old Domica Cave) and the Dlhá Chodba Cave (Long Passage Cave - a corridor between Domica and Baradla caves) they reach a length of $5,358 \mathrm{~m}$. They also form one generic unit with the Baradla Cave in Hungary with a total length of about $25 \mathrm{~km}$, from which almost one quarter is in Slovak territory. Currently, the show cave is $1,315 \mathrm{~m}$. The cave was formed in the Middle Triassic by pale Wetterstein limestones of the Silica Nappe along the tectonic faults by corrosive and erosive activities of the Styx stream and the Domicky Brook and smaller underground tributaries draining water mainly from the non-karst part of the basin. Air temperature ranges from 10.2 to $11.4{ }^{\circ} \mathrm{C}$ and relative humidity from 95 to $98 \%$. The cave system is an important wintering place for bats. Very numerous colonies of the Schreiber's Bats (Miniopterus schreibersiz) 
hibernated in the Čertova diera Cave in the past, and also dominant is the Mediterranean Horseshoe Bat (Rhinolophus euryale), which forms a unique colony of $1,200-1,400$ members in the Domica Cave. Thick layers of bat excrements - or guano - can be found in some places in this cave system (Anonymous, 2006; Bella, 1997; Droppa, 1961; Kladiva, 1995-2008).

\section{MATERIAL AND METHODS}

Samples for microfungal isolation were collected from various sites from the Domica Cave (both show cave tour and diversionary were sampled, DC), the Certova diera Cave (CD) and the Dlhá Chodba Cave $(\mathrm{DCH})$, i.e. from lighted and not lighted parts of the Domica Cave system (Figure 1).

Samples of cave (cave sediment, bat droppings and guano, earthworm casts, isopods and diplopods faeces, mammalian dung, frog and bat cadavers, bones, vermiculations, insects and other organic material) were collected aseptically in the spring and in the autumn of $2002-2007$ into sterile plastic bags, vessels or microtubes and they were kept cold during the transport to the laboratory.

Microscopic fungi were isolated in situ (mainly visible colonies of the order Mucorales on bat droppings and/or guano and other traces) or immediatelly after return to the laboratory (i.e., most five days after sampling) either directly by transferring a small amount of collected material into Petri dishes, or using the dilution plate method (Garrett, 1981). Martin`s soil extract agar, Sabouraud's agar and beer wort agar (all with rose bengal and chloramphenicol for the suppression of bacterial growth - these isolation media were found optimal for microfungal isolation from cave environment, while pure isolation media prepared e.g. from cave sediment extract were unsuitable considering low possibility of isolation) were used as isolation media (Kreisel \& Schauer, 1987). Air microfungi were isolated using the gravity settling culture plate method (Buttner \& Stetzenbach, 1991) and Sabouraud's agar as the isolation medium. Petri dishes were incubated in the dark at $25{ }^{\circ} \mathrm{C}$ for 7-10 days. Additionally, soil samples from aboveground environment were analysed and microfungal isolations from the outdoor air were carried out, too.

Identifications were carried out according to microand macromorphological characteristics using special identification media (MEA, CYA, Czapek-Dox agar, PDA, CA, OA, etc.) for all isolated micromycetes. Special taxonomic literature and compendia (Domsch et al., 1980, 2007; de Hoog et al., 2000) were used for the determination of microfungi. Taxonomic names are used according to Domsch et al. (2007).

\section{RESULTS AND DISCUSSION}

A total of 195 microfungal taxa (Zygomycetes, Ascomycetes and mitosporic fungi) belonging to 73 microfungal genera have been isolated during the study in the Domica Cave system (Table 1), and mainly saprotrophic filamentous microfungi were studied. The highest number of microfungal taxa (92) was found in samples of bat droppings and guano. Bat droppings and guano were collected in three parts of the Domica Cave system (the Čertova diera, Domica and Dlhá Chodba caves) - the guano heaps in the Domica Cave (Figure 2) and in the Čertova diera Cave make up the largest guano heaps in Central European caves. 15 microfungal taxa were isolated from Domica and Čertova diera caves, 11 taxa were obtained only from the Certova diera Cave, 52 taxa were isolated only

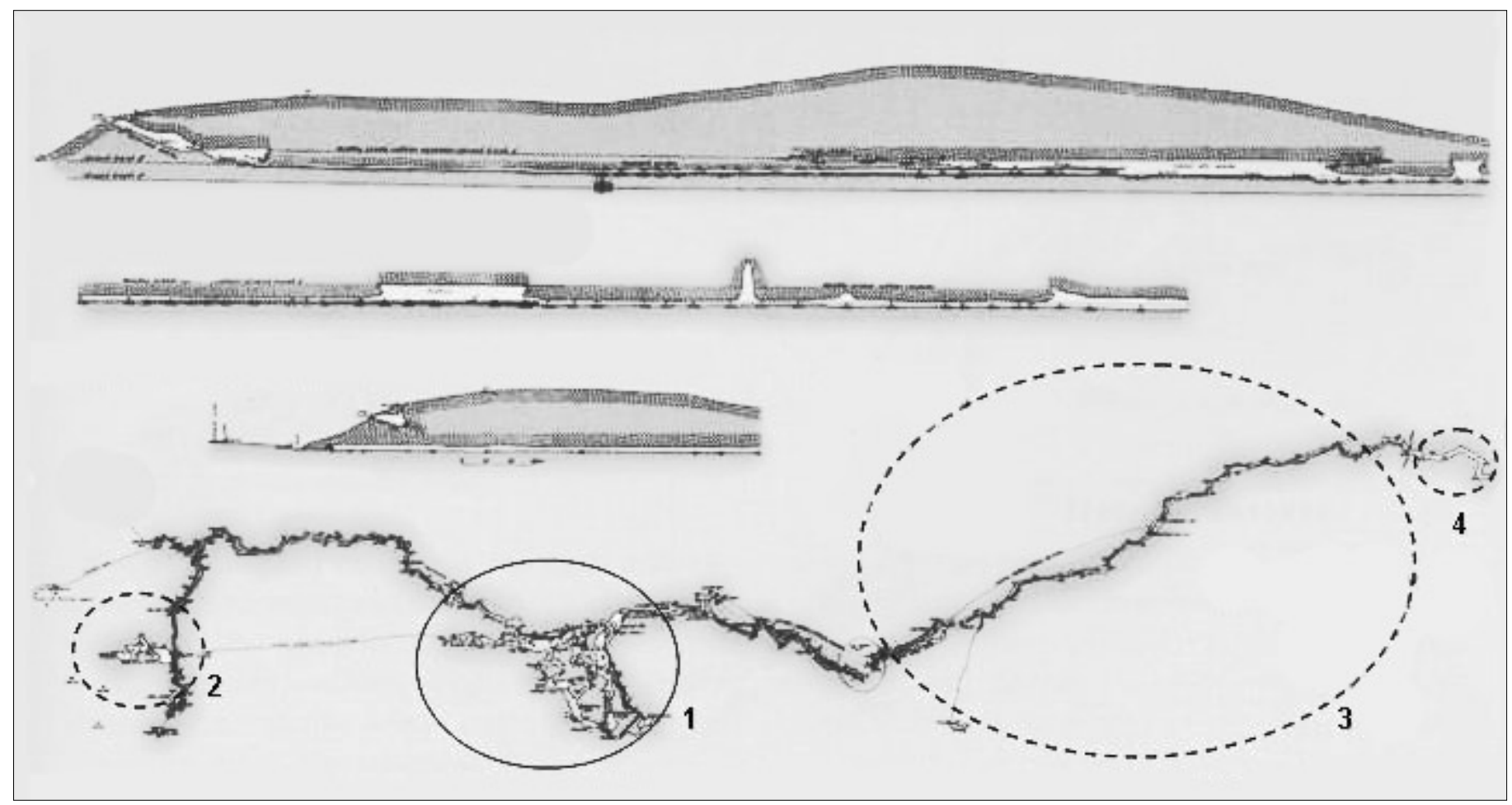

Fig. 1. A map of the Domica Cave system created by A. Droppa and A. Chovan - adapted according to Jakál (2005). Continuous line - show cave, broken line - non-tourist areas (1 - the Domica Cave, 2 - the Čertova diera Cave, 3 - the Dlhá Chodba Cave, 4 - Hungarian part of the Dlhá Chodba Cave). 
Tab. 1. A view of microfungal taxa isolated from the cave sediment air, bat droppings and/or guano, mammalian dung, earthworm casts, isopod and diplopods faeces, vermiculations, cadavers, and other substrates. 1 - the Domica Cave, 2 - the Čertova diera Cave, 3 - the Dlhá Chodba Cave, 4 - Hungarian part of the Dlhá Chodba Cave; frequent isolations are in bold.

\begin{tabular}{|c|c|c|c|c|c|c|c|c|c|}
\hline microfungal taxa & sediment & air & $\begin{array}{c}\text { bat } \\
\text { guano }\end{array}$ & $\begin{array}{l}\text { mammalian } \\
\text { dung }\end{array}$ & $\begin{array}{l}\text { earthworm } \\
\text { casts }\end{array}$ & $\begin{array}{l}\text { isopod } \\
\text { diplopod } \\
\text { faeces }\end{array}$ & vermiculations & cadavers & $\begin{array}{c}\text { other } \\
\text { substrates }\end{array}$ \\
\hline \multicolumn{10}{|c|}{ Zygomycetes: } \\
\hline Absidia cylindrospora var. cylindrospora & & & 2 & & 1 & & & & \\
\hline Absidia cylindrospora var. nigra & 1 & & & & & & & & \\
\hline Absidia glauca & & & 1 & & & & & & 3 \\
\hline Absidia spinosa & 1 & & & & & & & & \\
\hline Circinella sp. & & 3 & & & & & & & \\
\hline Coemansia aciculifera & & & & & 4 & & & & \\
\hline Mortierella spp. & 1 & & 1,3 & & 1 & 1 & & 1,3 & 1 \\
\hline Mucor circinelloides $f$. circinelloides & & 3 & 1 & & & & & & \\
\hline Mucor dimorphosporus f. dimorphosporus & 3 & 2 & 1 & & & & & & 3 \\
\hline Mucor dimorphosporus f. sphaerosporus & & 2 & 1,2 & & & & & & 3 \\
\hline Mucor hiemalis $f$. corticola & & & 2 & & & & & & \\
\hline Mucor hiemalis $f$. hiemalis & & 1,2 & 1,2 & & & & & & \\
\hline Mucor hiemalis $f$. silvaticus & & 1,2 & 1 & & 1 & & & 1 & \\
\hline ?Mucor mucedo & & & $1,2,3$ & & & & & & \\
\hline Mucor ramosissimus & & 1 & & & & & & & \\
\hline Mucor spp. & & & 1 & 1 & & & & & 1 \\
\hline Rhizopus arrhizus & & $1,2,3$ & & & & & & & \\
\hline Rhizopus stolonifer var. stolonifer & 2 & 2 & 1 & & & & & & \\
\hline \multicolumn{10}{|c|}{ mitosporic fungi: } \\
\hline Acremonium bactrocephalum & & & & & & 1 & & & \\
\hline Acremonium berkeleyanum & & 1 & 1,2 & & & 1 & & & \\
\hline Acremonium charticola & & & 1 & & & & & & \\
\hline Acremonium murorum & 1,2 & & 1 & & 1,2 & & & & 1 \\
\hline Acremonium polychromum & 1 & & & & & & & & \\
\hline Acremonium strictum & & & & & 1 & & & & \\
\hline Acremonium sp. & 1,3 & 2 & & & 1,3 & & & & \\
\hline Acrodontium sp. & & 1 & & & & & & & \\
\hline Acrostalagmus luteoalbus & $1,2,3$ & & & & & & & & \\
\hline Alternaria alternata & & $1,2,3$ & 1 & & & & & & 1 \\
\hline Arthrinium arundinis & & 1 & 1,2 & & 1 & & & & \\
\hline Arthrinium phaeospermum & 1,3 & & & & 2 & & & & \\
\hline Aspergillus candidus & & 1 & & & & 1 & & & \\
\hline Aspergillus clavatus & & & 1 & & & & & & \\
\hline Aspergillus flavus group & 3 & & & & & & & & \\
\hline Aspergillus fumigatus & 3 & 1,2 & 1,2 & & 1,2 & & & & \\
\hline Aspergillus niger group & & & 2 & & & & & & \\
\hline Aspergillus phoenicis & 1 & & & & 1 & & & & 1 \\
\hline Aspergillus puniceus & & & & & 2 & & & & \\
\hline Aspergillus ustus & & 1 & & & & & & & 1 \\
\hline Aspergillus versicolor & & 1,2 & & & & 1 & & & \\
\hline Aspergillus sp. & 1,2 & 1,3 & 2 & & & 1 & 1 & & 1 \\
\hline Beauveria bassiana & $1,2,3$ & 1,2 & 1,2 & & & & & & 1 \\
\hline Beauveria brongniartii & & 1 & & & & & & & 1 \\
\hline Botryosporium longibrachiatum & & & & & & & & 1,4 & \\
\hline Botryotrichum piluliferum & 1 & & 2 & & & & & & \\
\hline Botrytis cinerea & & 2 & & & 2,3 & & & & \\
\hline
\end{tabular}




\begin{tabular}{|c|c|c|c|c|c|c|c|c|c|}
\hline Chloridium virescens var. candigerum & & & & & 1 & & & & \\
\hline Chrysosporium speluncarum & & & 2 & & & & & & \\
\hline Chrysosporium sp. & 1,4 & 1 & 1,2 & & 1,2 & & 3 & & \\
\hline Cladosporium cladosporioides & 1 & $1,2,3$ & & & & & & & \\
\hline Cladosporium herbarum & 1 & $1,2,3$ & & & & & & & \\
\hline Cladosporium cf. elatum & & 1,2 & & & & & & & \\
\hline Cladosporium sphaerospermum & & 1,2 & & & & & & & \\
\hline Cladosporium tenuissimum & & 1 & & & & & & & \\
\hline Cladophialophora sp. & & & 1 & & 1 & & & & \\
\hline Clonostachys candelabra & & 2 & & & & & & & \\
\hline Clonostachys rosea f. rosea & 1 & & 1,2 & & 1 & 3 & & & \\
\hline Clonostachys sp. & 3 & & & & & & & & \\
\hline Cylindrocarpon destructans & & & & & 1 & & & & \\
\hline Cylindrocarpon sp. & & & & & 1 & 3 & & & \\
\hline Doratomyces microsporus & 1 & & & & & 3 & & & \\
\hline Doratomyces nanus & & & 1,2 & & 2 & 3 & & & \\
\hline Doratomyces stemonitis & 1,2 & 4 & 1,2 & & & & & & \\
\hline $\begin{array}{c}\text { Echinobotryum state of Doratomyces } \\
\text { stemonitis }\end{array}$ & 3 & & 1,2 & & & 3 & & & \\
\hline Emericellopsis terricola & 1 & & & & & & & & \\
\hline Engyodontium album & 2 & 1,2 & & & & & & & \\
\hline Fusarium solani & & & 1 & & & & & & \\
\hline Fusarium sporotrichoides & 1 & & & & & & & & \\
\hline Fusarium spp. & 1,4 & 2,3 & 1 & & 1 & & 1 & & \\
\hline Geomyces pannorum var. pannorum & 1 & 1 & 1,2 & & 1,2 & 3 & & & \\
\hline Geotrichum candidum & & & 1 & & & & 3 & & 1 \\
\hline Hormiactis sp. & & & 1 & & 1 & & & & \\
\hline Humicola fuscoatra & 1,3 & & 1 & & & & & & 1 \\
\hline Humicola grisea & 1,2 & & 2 & & 1,2 & & & & \\
\hline Humicola sp. & & & & & 1 & & & & \\
\hline Hypocrea sp. & & & 1 & & & & & & \\
\hline Isaria farinosa & $1,2,3$ & 2,3 & 1,2 & & 1 & & & & 1 \\
\hline Isaria fumosorosea & 1 & & 2 & & 2 & & & & \\
\hline Lecanicillium muscarium & 1 & & 1 & & & & & & 1 \\
\hline Lecanicillium psalliotae & & 2 & & & & & & & \\
\hline Malbranchea sp. & 1,4 & 2 & 1 & & 4 & & & & \\
\hline Mammaria echinobotryoides & 1 & & & & 2 & & & & \\
\hline Metarhizium anisopliae & & & & & & & & 3 & \\
\hline ?Myceliophtora velerea & & 1 & & & & & & & \\
\hline Myrothecium roridum & 3 & & 2 & & 3,4 & & & & \\
\hline Myrothecium verrucaria & 2,1 & & & & & & & & \\
\hline Myxotrichum deflexum & 1,3 & & 2 & & 1 & & 1 & & \\
\hline $\begin{array}{c}\text { Ochroconis (Scolecobasidium) } \\
\text { tschawytschae }\end{array}$ & & 3 & & & & & & & \\
\hline Oidiodendron cerealis & 1,3 & 3 & 1 & & 1,3 & & 1,4 & & 1,3 \\
\hline Oidiodendron citrinum & & & 1 & & & & & & \\
\hline Oidiodendron griseum & 1,2 & & 1 & & & & 3 & & \\
\hline Oidiodendron tenuissinum & 1 & & & & & & & & \\
\hline Oidiodendron sp. & 3 & & 1 & & & & & & \\
\hline Paecillium lilacinum & 1,3 & 1 & 1 & 1 & 1,3 & 1 & & & \\
\hline Paecilomyces marquandii & 1 & & 3 & & 1 & 3 & & & \\
\hline Paecilomyces variotii & $1,2,3$ & & 1,2 & & 1 & & & & \\
\hline Paecilomyces sp. (white) & 3 & & & & & & & & \\
\hline Paranomuraea carnea & 1,3 & 1,2 & 1,3 & & 1,2 & & 1,3 & & 1 \\
\hline
\end{tabular}


Penicillium atramentosum

Penicillium aurantiogriseum

Penicillium chrysogenum

Penicillium citrinum

Penicillium commune

Penicillium corylophilum

Penicillium daleae

Penicillium decumbens

Penicillium echinulatum

Penicillium expansum

Penicillium glabrum

Penicillium glandicola

Penicillium hirsutum

Penicillium hordei

Penicillium janczewskii

Penicillium janthinellum

Penicillium melanoconidium

Penicillium melinii

Penicillium minioluteum

Penicillium paxilli

Penicillium pinophilum

Penicillium purpurescens

Penicillium purpurogenum

Penicillium restrictum

Penicillium roqueforti

Penicillium rugulosum

Penicillium sacculum

Penicillium scabrosum

Penicillium solitum

Penicillium thomii

Penicillium variabile

Penicillium viridicatum

Penicillium vulpinum

Penicillium waksmanii

Penicillium sp.

Periconia cf. macrospinosa

Phialophora sp.

Phoma eupyrena

Phoma lingam

Phoma sp.

Pithomyces chartarum

Pochonia chlamydosporia var. catenulata

Pochonia chlamydosporia var.

chlamydosporia

Ramichloridium $s p$.

Scopulariopsis brumptii

Scopulariopsis chartarum

Scopulariopsis croci

Scytalidium lignicola

Simplicillium lamellicola

Stachybotrys chartarum

Stachybotrys cylindrospora

Tetraccosporium paxianum

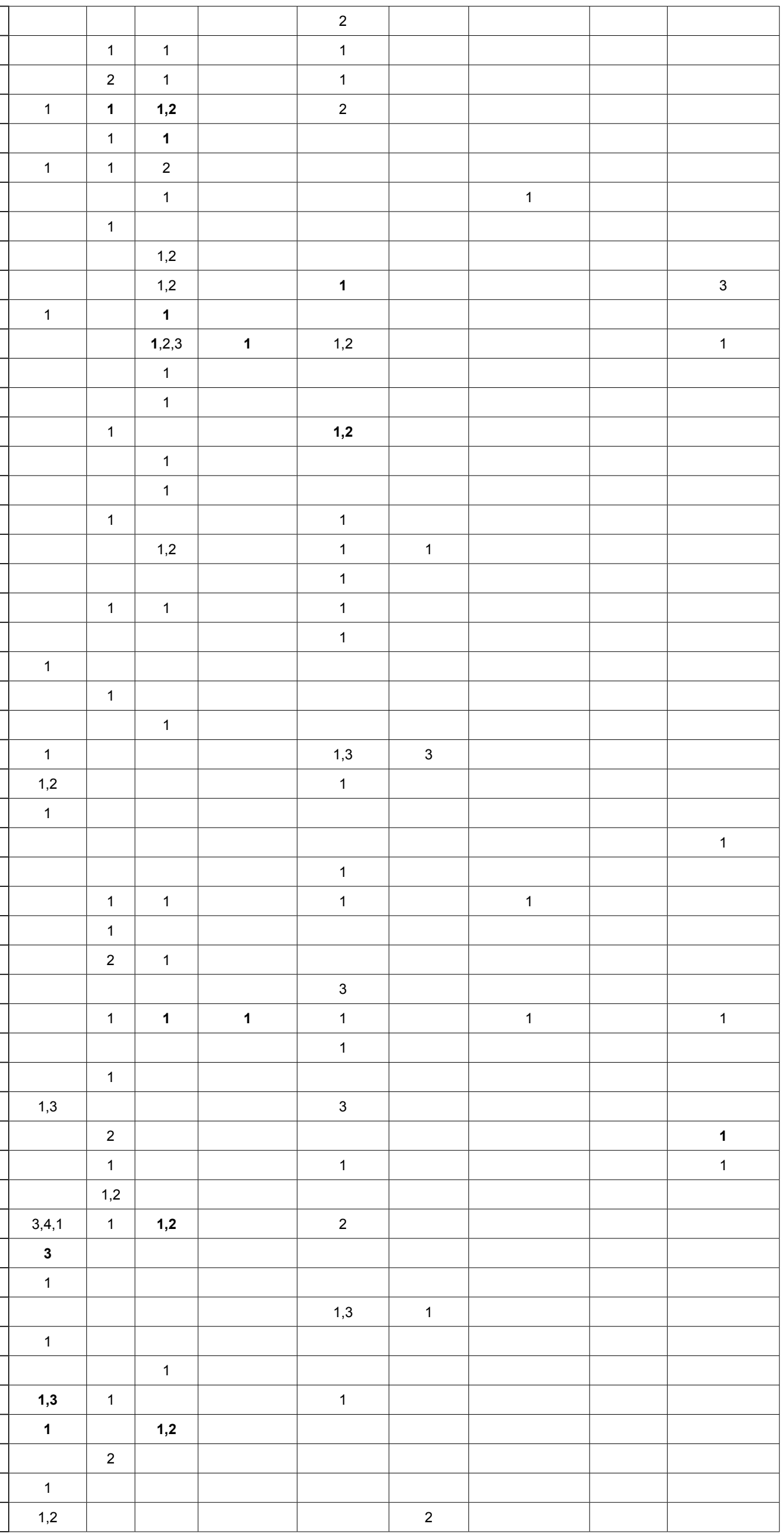




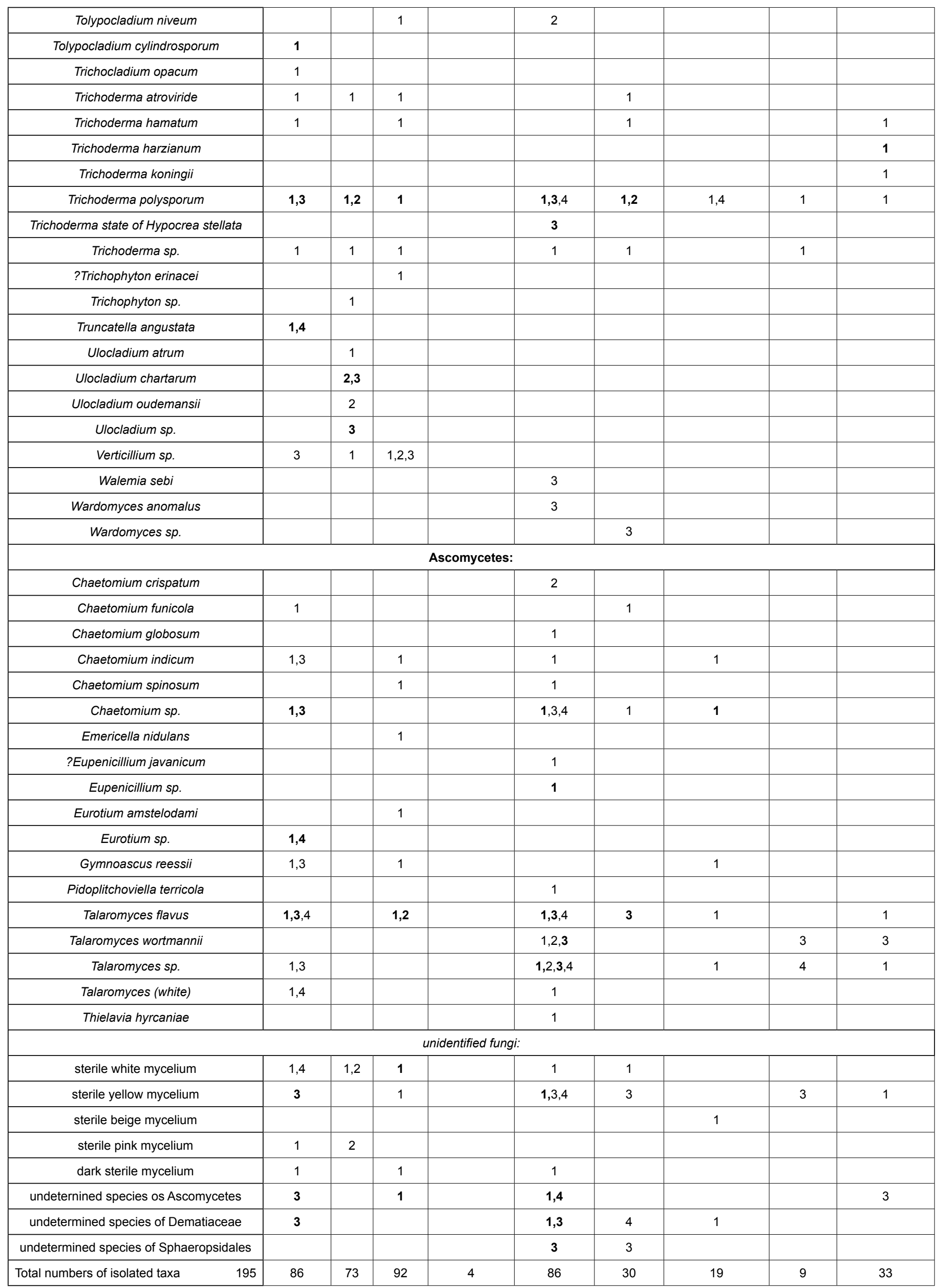




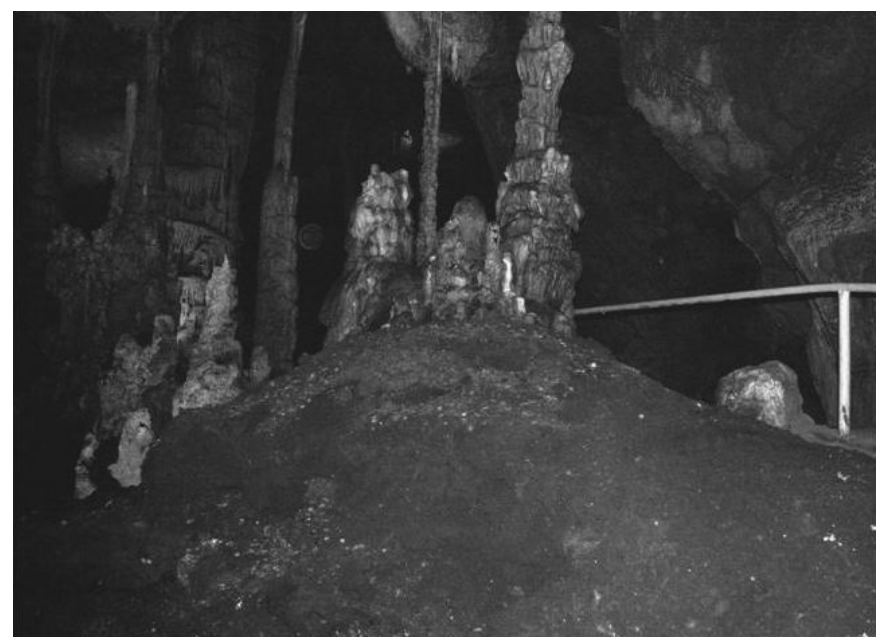

Fig. 2. Guano heap in the Palmy Grove Dome in the Domica Cave the greatest guano heap in Central Europe caves (depth of $103 \mathrm{~cm}$, heap base of $440 \times 350 \mathrm{~cm}$ ).

from the Domica Cave and six microfungal taxa were found in bat droppings and/or guano samples from all parts of the Domica Cave system. Several microfungal taxa were isolated from this material repeatedly, e.g. Absidia glauca, Acremonium berkeleyanum, Alternaria alternata, Aspergillus clavatus, A. fumigatus, Chrysosporium sp., Clonostachys rosea f. rosea, Geomyces pannorum var. pannorum, Lecanicillium muscarium, Mucor spp., Oidiodendron cerealis, $O$. griseum, Oidiodendron sp., Doratomyces stemonitis and its co-anamorph Echinobotryum (Figure 3), Trichoderma polysporum (Figure 4), Paranomuraea carnea, Penicillium citrinum, P. glandicola (Figure 5), Rhizopus arrhizus, and Ulocladium sp. Oidiodendron cerealis, Doratomyces stemonitis with co-anamorph Echinobotryum, and Trichoderma polysporum were the most frequently isolated species, and may represent typical microfungal species on bat traces. Species of the genus Mucor which create visible colonies on bat droppings and on the surface of guano heaps were also isolated with high frequency using direct isolation in situ. In all, about 30 species of this genus differing in micro- and macromophological properties were recognised from this substrate - unfortunately they were not determined because a monograph with a modern concept of this genus was not available at that time. Eleven microfungal species were found only from bat droppings and/or guano and were not found in other studied materials (see Table 1). White and yellowish pustules were found on bat droppings in the Domica Cave system as well as in other caves in the NP Slovak Karst, but the isolation was unsuccessful. Finally, Trichoderma polysporum, one of the white-coloured Trichoderma species, was determined from white colonies. In microscopic slides prepared from yellowish microfungal colonies on bat droppings, tuberculate conidia resembling anamorph of Ajellomyces capsulatus were observed. Considering the successful isolation of this fungus from bat guano in 2006 and consequential analyses including molecular techniques, novel Chrysosporium species, C. speluncarum, was described (Nováková \& Kolařík, in press).
A broad spectrum of microfungal species are known from previous studies of microfungi from bat droppings and guano; e.g., Larcher et al. (2003) revealed the great fungal diversity from 82 studied samples of bat guano from caves of Western France, including pathogenic yeasts, eight species of keratinophilic fungi, and one onygenalean fungus highly resembling Histoplasma capsulatum. Trichosporon laibachii, T. porosum and seven new Trichosporon species, eight ascomycetous yeasts and one basidiomycetous yeast were reported from bat guano samples from bat-inhabited caves in Japan (Sugita et al., 2005). Ulloa et al. (2006) isolated four ascomycetal species from bat guano samples collected in several Mexican caves (Aphanoascus fulvescens, Gymnascella citrina, Gymnoascus dankaliensis, Chaetomidium fimeti), six mitosporic fungi (Aspergillus flavofurcatis, A. terreus, A. terreus var. aureus, Penicillium spp., Malbranchea aurantiaca, and Sporothrix sp.), and five yeasts (Rhodotorula spp., Candida catenulata, C. cifferii, C. famata var. flareri, and C. guilliermondii var. guilliermondii). Several morphological types of yeasts were also found between isolated filamentous microfungi, but they were not isolated in this study.

Important differences in species diversity and numbers of isolated microfungal species from bat droppings and/or guano were found between our results and literature records. Low microfungal numbers and pure spectrum which are reported in some above mentioned papers quite agree with using isolation techniques and mainly with short-time of investigation.

Microfungal studies in the Baradla Cave, a part of the Domica-Baradla Cave System in Hungary, performed in the 1960s by Zeller (1962, 1966, 1967, 1968, 1970) targeted microfungal isolation largely using the To$\mathrm{Ka}-\mathrm{Va}$ baiting method, and some microfungal species were also isolated using the dilution plate method. Arthoderma quadrifidum, A. currei, A. tuberculatum, Trichophyton terrestre, Myxotrichum chartarum, M. deflexum, Chrysosporium evolceanui, Circinella simplex, Rhizopus arrhizus, $R$. nigricans, $R$. delemar, and Absidia corymbifera were isolated from bat guano in these studies. Myxotrichum deflexum was also isolated from guano samples from the Čertova diera Cave and repeatedly from cave sediment (DC, $\mathrm{DCH}$ ) and earthworm casts (DC), and in one case this species was found from vermiculations (DC), too (see Table 1).

Some differences in microfungal diversity in cave sediments and earthworm casts (Figure 6a, b) were found after six years of investigations, but in total 86 taxa were isolated from both substrates even though a higher number of cave sediments were analysed compared to the number of sampled earthworm casts, although species richness always seemed to be higher in earthworm casts. The greater part of the isolated microfungal taxa was found in both substrates, some of which were isolated repeatedly, but several taxa were recorded only from casts (e.g., Chaetomium crispatum, Doratomyces nanus, Tolypocladium niveum, Talaromyces wortmannii, 

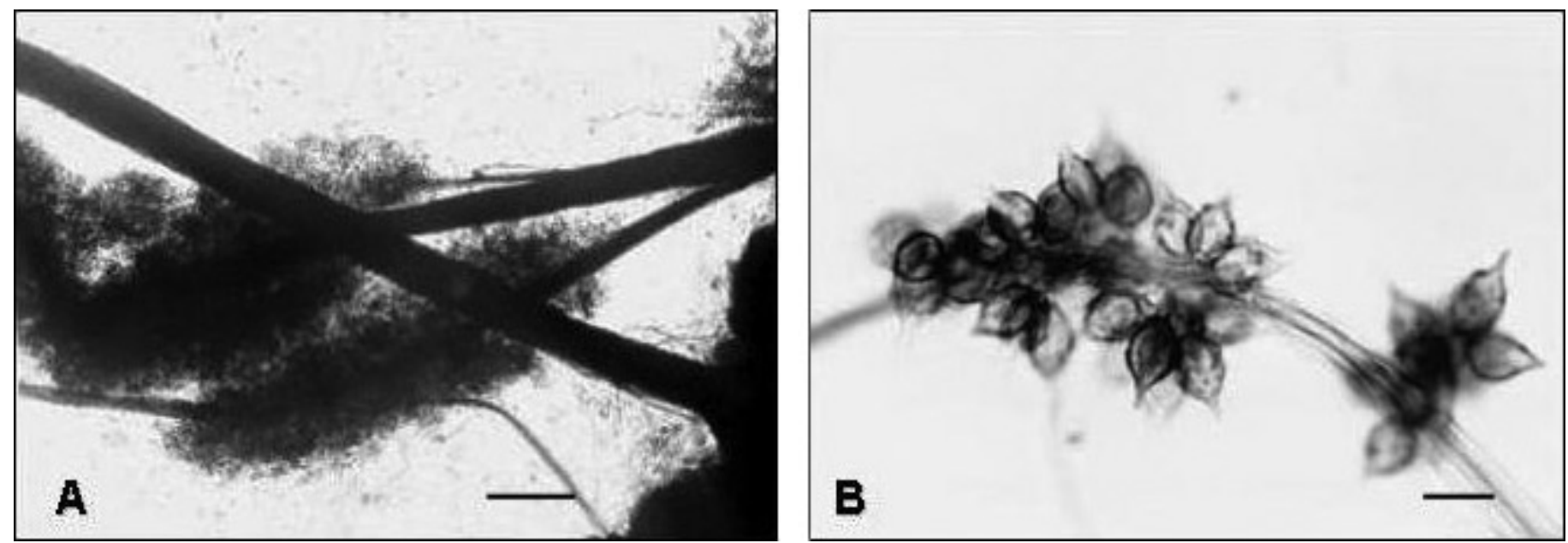

Fig. 3. Doratomyces stemonitis and its co-anamorph Echinobotryum - A - synnemata of D. stemonitis (bar $=20 \mu \mathrm{m}$ ); $\mathrm{B}-$ Echinobotryum type aleurioconidia $($ bar $=10 \mu \mathrm{m})$.
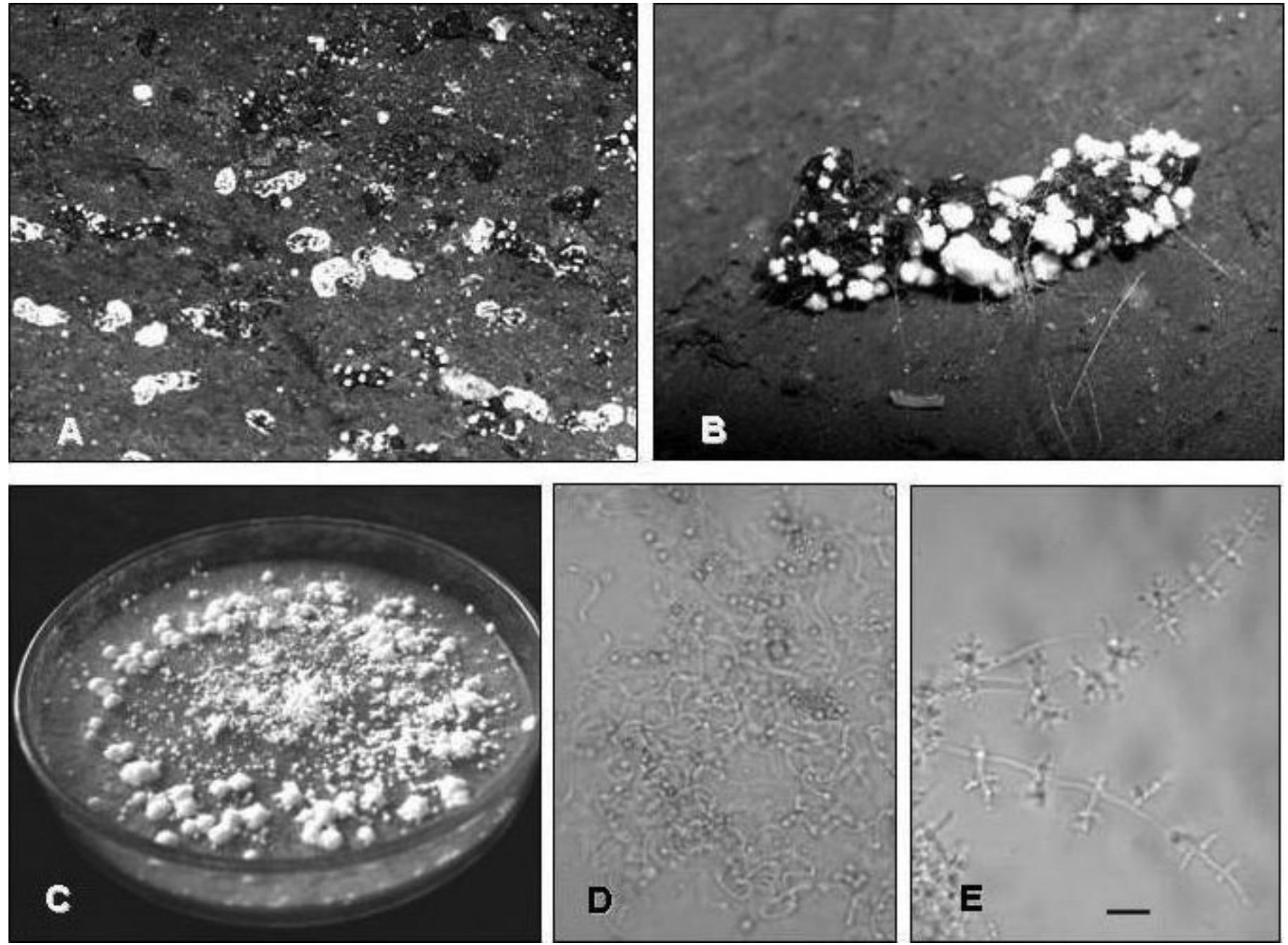

Fig. 4. A - Bat droppings with white microfungal colonies; B - bat dropping with white pustules of Trichoderma polysporum, photo J. Stankovič; C - T. polysporum, 10 days colony on malt extract agar (MEA); D, E - T. polysporum - typical conidiophores and sterile apical elongations $($ bar $=10 \mu \mathrm{m})$.

Wallemia sebi, and Wardomyces anomalus) or cave sediments (Arthrinium phaeospermum, Aspergillus fumigatus, Eurotium sp., Doratomyces microsporus, D. stemonitis and its co-anamorph Echinobotryum, and Emericellopsis terricola). Talaromyces flavus (Figure 6c) was found in both of these substrates, but more frequently it was isolated from earthworm casts. Rutherford \& Huang (1994) discussed the isolated microfungal spectrum from remote sediments in West
Virginia caves together with results of several works dealing with microfungi occurrence in sediments (and some other substrates such as dung, active cave formations, living organisms, wood and plant debris etc.) of different caves and soils in above-ground environments from around the world. They isolated 35 fungal taxa and Mycelia sterilia were found to be the most prominent forms, followed in decreasing order by Aspergillus aureolatus, Byssochlamys fulva, 

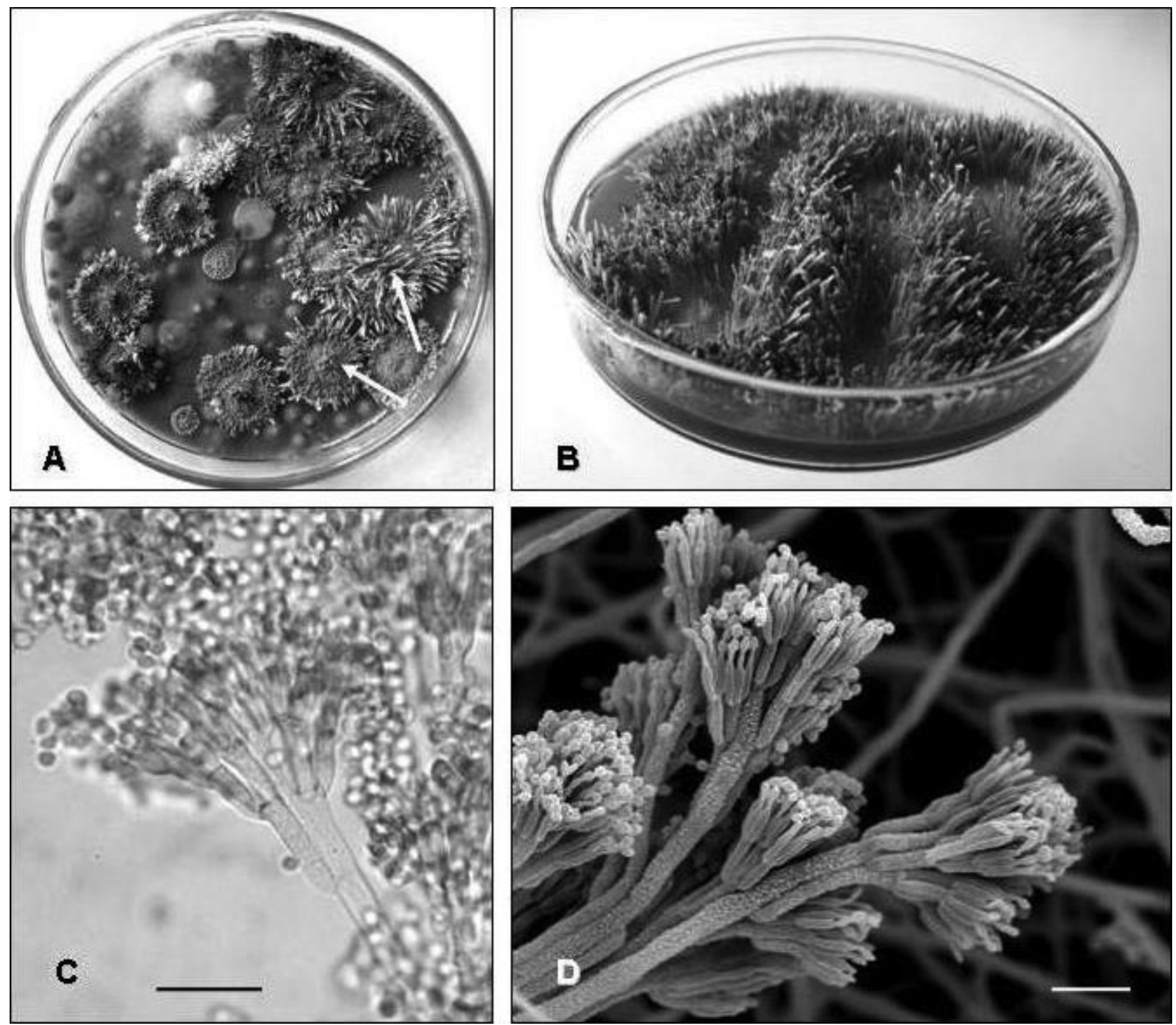

Fig. 5. A - Petri dish with microfungal colonies isolated from bat guano (Čertova diera Cave), arrows show colonies of Penicillium glandicola; B P. glandicola, 7 days synnematous colony on MEA; C - conidiophore with conidia, $x$ 900; D - conidiophores, SEM, $x 2500$ (bar $=10 \mu \mathrm{m}$ ).
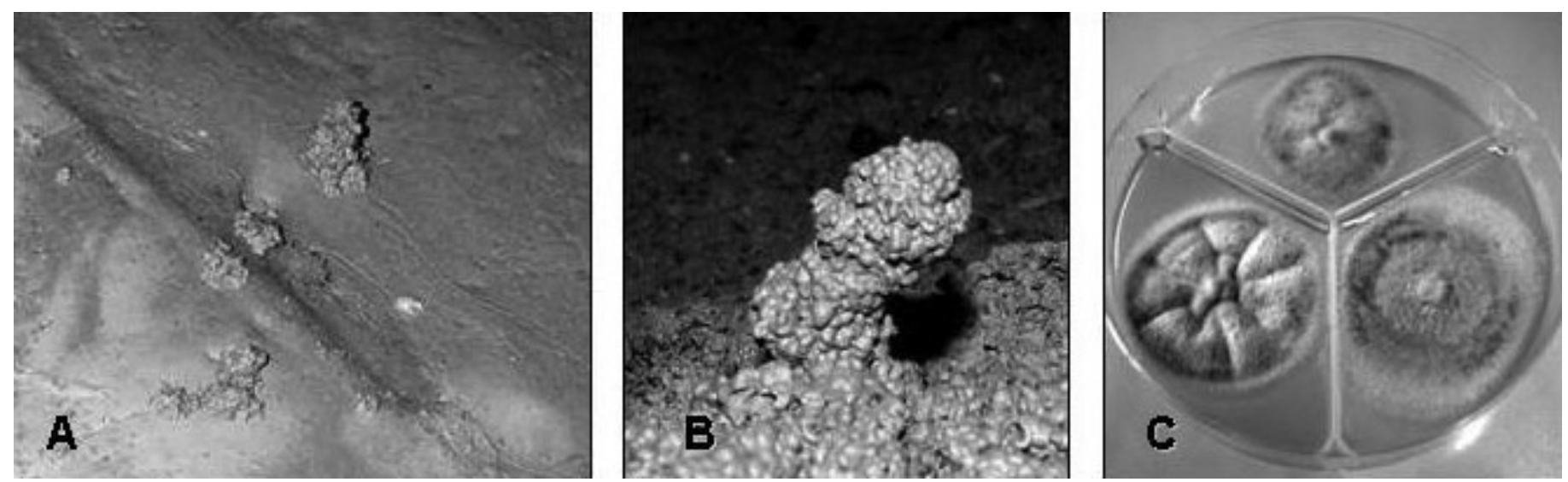

Fig .6. A - Earthworm casts on Styx stream bank in the Domica Cave; B - funny shaped earthworm cast near Japanese Teahouse in the Domica Cave; C - Talaromyces flavus, 10 days colonies on Czapek-Dox agar, CYA and MEA.

Penicillium steckii, Gliocladium roseum, Paecilomyces variotii, Mortierella alpina, Aspergillus caespitosus, and Fusarium oxyporum. Aspergillus fumigatus was also reported from cave sediments by Griffiths (1979). A broad spectrum of micromycetes was found from a bat cave in the Bahamas (Orpurt, 1964), Polish caves (Nespiak, 1970), the Hungarian cave Baradla (Zeller, 1962, 1966, 1968, 1970), and "la Salle de la Verna" in the French cave of Pierre St. Martin (Seigle-Murandi et al., 1980). 
Bosák et al. (2001) reported 151 microfungal taxa from four Moravian caves (Zbrašov Aragonite Caves, Javořičko Caves, Punkva Caves, and Amatérská Cave) - 109 taxa were isolated from cave air, 56 taxa from aragonite speleothems in the Zbrašov Aragonite Caves, 35 taxa from cave sediment in the Javořičko Caves and 13 taxa from soda straw stalactites. A higher number of microfungal taxa was found in the touristic Punkva Caves and the most frequent fungi in this cave were Aureobasidium pullulans, Chrysosporium merdarium, Cladosporium cladosporioides, C. herbarum, $C$. sphaerospermum, Geomyces pannorum, Penicillium brevicompactum, P. vulpinum and basidiomycetous anamorphs, whereas four microfungal species were isolated from all studied substrates (C. macrocarpum, Geomyces pannorum, Mortierella alpina, and $P$. aurantiogriseum), but 89 species were isolated only from one type of the studied substrates.

A comparison of the obtained microfungal spectrum from cave sediments of the Domica Cave system with microfungi isolated from soils collected above the studied cave system shows that they have very different microfungal communities. Microfungal species commonly isolated from soils were not obtained from cave sediments.

No records about micromycete occurrence in earthworm casts were published from cave environment and the same situation applies to studies of micromycete occurrence in other invertebrate traces such as isopods or diplopods which are abundant cave-dwelling organisms. In this study, a total of 30 microfungal taxa have been found from isopod and diplopod faeces while some of these were recorded only from this substrate (e.g., Acremonium bactrocephalum, unidentified species of Sphaeropsidales, and Wardomyces sp.)

Analogically, the microfungal occurrence in cave air was also occasionally studied (Figure 7). In this study, a total of 73 microfungal taxa were estimated in cave air. In comparison with outdoor mycoflora, the microfungal diversity in cave air was rather higher, but quantitative parameters (spore number in cubic meter of air) were lower. No effect on quantitative occurrence of air microfungi caused by visitors was recorded. On the contrary, Bosák et al. (2001) compared mycobiota in four Moravian caves differing in number of visitors and reported differences in species composition including the microfungal spectrum in cave atmosphere. Very interesting is the occurrence of several species of the genus Aspergillus (DC, CD), because they are treated as allergenic for humans, including $A$. fumigatus, which is a potential pathogen (Domsch et al., 2007). This species was also found in cave air in the tourist Punkva Caves (Bosák et al., 2001). Several Cladosporium species, the entomopathogenic species Isaria farinosa, Trichoderma polysporum, and Ulocladium chartarum were isolated repeatedly.

Vermiculations on cave walls and speleothems were sampled only in the last two years and while 19 microfungal taxa were found in this material, only one species, Geotrichum candidum, was isolated repeatedly. In the past, various theories about vermiculation origin as well as participation in the processes of development of these formations on cave walls and speleothems were published (Anelli \& Graniti., 1967; Bini et al., 1978; Northup et al., 2000; Northup \& Lavoie, 2001; Barton, 2006; Barton \& Northup, 2007). Camassa \& Febroriello (2003) speculated that Geotrichum sp. plays an important role in the processes of vermiculation development.

Nine microfungal taxa were isolated from mammalian cadavers and bones and 33 taxa from other materials such as dead insect bodies on cave walls in the entrance parts of caves, microfungal colonies on walls and speleothems, decaying plant debris or wood material etc. Entomopathogenic species such as Beauveria bassiana, B. brongniartii, Isaria farinosa, and Lecanicillium muscarium were found on insect bodies or on walls in the entrance parts of caves. Aspergillus ustus, Phoma lingam, and Trichoderma harzianum were repeatedly isolated from plant debris or decaying wood material.

\section{CONCLUSIONS}

Our long-time studies of microscopic fungi in the Domica Cave system showed a very broad microfungal spectrum, specially in cave air, sediments, invertebrate faeces and bat droppings and/or guano. Apparently, a very specific microfungal community exists in the underground environment, particularly when there are organic matter inputs. These findings are interesting mainly because micromycetes can be a potential food source
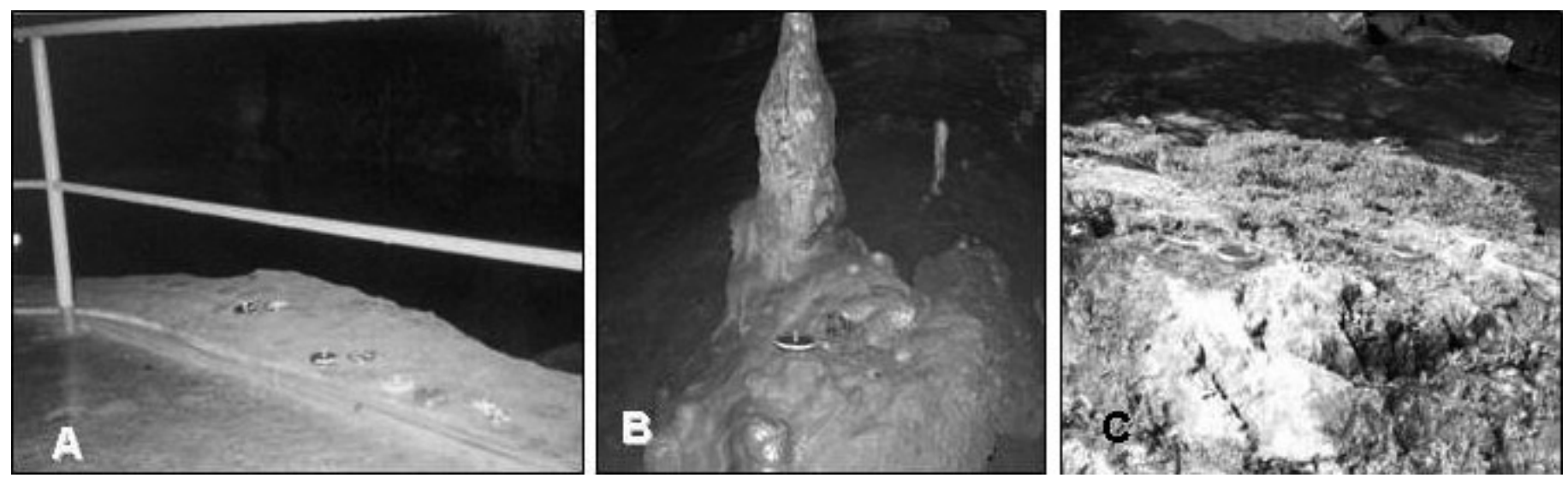

Fig. 7. Gravity settling culture plate method - isolation of air-borne micromycetes from cave air - A, B and from outdoor - C. 
for cave invertebrates (together with cave bacteria and algae). D. stemonitis and its co-anamorph Echinobotryum together with D. microsporus and D. nanus, Oidiodendron cerealis, and Trichoderma polysporum were the most frequently isolated species from bat droppings/guano. Talaromyces flavus was frequently isolated from earthworm casts and cave sediment and Penicillium glandicola was found as characteristic species on marten dung and in bat guano, too. Interesting findings are also rare isolated (Pidoplitchkoviella terricola) or novel species (Chrysosporium speluncarum, sp. nov.).

It appears evident that in next studies it will be necessary to use also other isolation methods e.g., the bait technique with various type of bait, the soil washing technique and methods of molecular biology (identification of isolated strains, estimation of noncultivated microfungi in cave substrates).

\section{ACKNOWLEDGEMENTS}

Work was supported by the Research Plan of the ISB BC AS CR, v.v.i. No AV0Z60660521. The author is grateful to the Slovak Cave Administration for allowing entry to caves, to L'ubomir Kováč, Andrej Mock and Peter Luptáčik for helping during sampling in caves and to Jaroslav Stankovič for the photo of the bat dropping.

\section{REFERENCES}

Anonymous, 2006 - http://www.ssj.sk/, Slovak Caves Administration, Liptovský Mikuláš.

Anelli F. \& Graniti A., 1967 - Aspetti microbiologici nella genesi delle vermicolazioni argillose delle Grotte di Castellana (Murge di Bari). Grotte d'Italia, serie IV, 1: 131-140.

Barton H.A., 2006 - Introduction to cave microbiology: a review for the non-specialists. Journal of Cave and Karst Studies, 68: 43-54.

Barton H.A. \& Northup D.E., 2007 - Geomicrobiology in cave environments: past, current and future perspectives. Journal of Cave and Karst Studies, 69: 163-178.

Bella P., 1997 - Show caves in Slovakia. Knižné centrum, Žilina, $62 \mathrm{p}$.

Bini A., Cavelli Gori M. \& Gori S., 1978 - A critical review of hypotheses on the origin of vermiculations. International Journal of Speleology, 10: 11-33.

Bosák P., Vašátko J., Cílek V., Dumnicka E., Hanuláková D., Horáček I., Jeník J., Kopečký J., Marvanová L., Mlejnek R., Růžička V. \& Zacharda M., 2001 - Czech Republic. In: Juberthie C. \& Decu C. (Eds.), Encyclopaedia Biospéologica III, Société de Biospéléologie, Moulis - Bucarest, pp. 1405-1426.

Camassa M.M. \& Febroriello P., 2003 - Le foval della grotta Zinzulusa in Puglia (SE-Italia). Thalassia Salentina 26 Supplemento: Il Carsismo nell’Area Mediterranea, pp. 207-218.

de Hoog G.S., Guarro J., Gené J. \& Figueras M.J., 2000 - Atlas of Clinical Fungi. 2nd ed. CBS and Universitat Rovira i Virgili, Utrecht and Reus, $1126 \mathrm{p}$.

Domsch K.H., Gams W. \& Anderson T.-H., 1980 Compendium of Soil Fungi. Vol. 1, Academic Press, London etc., $859 \mathrm{p}$.
Domsch K.H., Gams W. \& Anderson T.-H., 2007 Compendium of Soil Fungi. 2nd ed., IHW Verlag, Eching bei München, $672 \mathrm{p}$.

Droppa A., 1961 - Domica - Baradla. Caves of the prehistoric man. Šport, Bratislava, 150 p. [In Slovak with Russian, Hungarian, German and English summary]

Elhottová D., Krištůfek V., Nováková A., Kováč L., Mock A. \& Luptáčik P., 2003 - Domica and Ardovská caves - study of interactions between fauna and microflora. Aragonit, 8: 38-40. [In Slovak]

Elhottová D., Krištůfek V., Nováková A., Lukešová A., Třiska J., Kováč L., Mock A. \& Luptáčik P., 2004 - Sources of polyunsaturated fatty acids in caves of Slovak Karst. In: Bella P. (Ed.), "Research, Utilization and Protection of Caves", $4^{\text {th }}$ Scientific Conference with International Participation, Tále, 5.-8.10. 2003, Liptovský Mikuláš, pp. 155-161. [In Czech with English abstract]

Garrett S. D., 1981 - Soil fungi and soil fertility. 2nd Ed. Pergamon Press, Oxford etc., 150 p.

Griffiths P., 1979 - Collection, culture and identification of soil microfungi from Florence Lake Cave near Victoria, B.C. Canadian Caver, 10: 35-38.

Jakál J. (Ed.), 2005 - Caves of the world heritage in Slovakia. Slovak Caves Administration, Liptovský Mikuláš, 159 p. [in Slovak]

Kladiva E., 1995-2008 - The Domica Cave. http:// www.saske.sk/cave/slk/domica.html

Kreisel H. \& Schauer F., 1987 - Methoden des mykologischen Laboratoriums. Jena, 181 p.

Larcher G., Bouchara J.P., Pailley P., Montfort D., Béguin H., de Bièvre C. \& Chabasse D., 2003 Fungal biota associated with bats in Western France. Journal de Mycologie Médical, 13: 29-34.

Lukešová A. \& Nováková A., 2008 - Interactions between soil micro-flora and invertebrates in Slovak and Moravian caves. In: Tajovský K., Schlaghamerský J. \& Pižl V. (eds.), Contributions to Soil Zoology in Central Europe III. ISB AS, České Budějovice. (in press)

Nespiak A., 1970 - Quelques observations sur les champignons isolés de l'interieur des grottes polonaises dans les montagnes Tatras et Sudètes. Schweizerische Zeitschrift für Pilzkunde. 48: $107-110$.

Northup D.E., Dahm C.N., Melim L.A., Spilde M.N., Crossey L.J., Lavoie K.H., Mallory L.M., Boston P.J., Cunningham K.I. \& Barns S.M., 2000 - Evidence for geomicrobiological interactions in Guadalupe caves. Journal of Cave and Karst Studies, 62: 80-90.

Northup D.E. \& Lavoie K.H., 2001 - Geomicrobiology of caves: a review. Geomicrobiological Journal, 18:199222.

Nováková A., 2004a - Microscopic fungi in caves of the National Park Slovak Karst. Phytopedon, 3: 26-31.

Nováková A., 2004b - Saprotrophic microscopic fungi in caves of the Slovak Karst National Park. In: Bella P. (Ed.), "Research, Utilization and Protection of Caves", $4^{\text {th }}$ Scientific Conference with International Participation, Tále, 5.-8.10. 2003, Liptovský Mikuláš, pp. 162-168. [In Czech with English abstract] 
Nováková A., 2005 - Interesting and rare saprothrophic microfungi isolated from excrements and other substrata in the Domica and Ardouská Caves (Slovak Karst National Park, Slovakia). In: Tajovský K., Pižl V. \& Schlaghamerský J. (Eds), Contributions to Soil Zoology in Central Europe I., Proceedings of the 7th Central European Workshop on Soil Zoology, České Budějovice, April 14-16, 2003, pp. 109-112.

Nováková A., 2006 - Microscopic fungi in selected caves of Czech and Slovak Republics. In: Šimonovičová A., Dlapa P., Mičuda,R. (Eds.), Life in soil VII., Bratislava, 24.-25.1.2006, CD-ROM, Bratislava, pp. 240-250. [In Czech with English abstract]

Nováková A., 2008 - Microscopic fungi in cave sediments and vermiculations - a pilot study. In: Šimonovičová A., Dlapa P., Mičuda R. (Eds.), Life in soil IX., Bratislava, 30.-31.1.2008, CD-ROM, Bratislava. (in press) [In Czech with English abstract]

Nováková A. \& Kolařík M., 2008 - Chrysosporium speluncarum, a new species resembling Ajellomyces capsulatus, obtained from bat guano in caves of Central Europe. Antonie van Leeuwenhoek (in press)

Nováková A., Elhottová D., Krištůfek V., Lukešová A., Hill P., Kováč L., Mock A. \& Luptáčik P., 2005 - Feeding sources of invertebrates in the Ardovská Cave and Domica Cave systems - preliminary results. In: Tajovský K., Pižl V. \& Schlaghamerský J. (Eds), Contributions to Soil Zoology in Central Europe I., Proceedings of the 7 th Central European Workshop on Soil Zoology, České Budějovice, April 14-16, 2003, pp. 109-112.

Nováková A., Kolařỉk M. \& Chroňáková A., 2008 Histoplasma capsulatum - a danger for visitors in caves of Middle Europe? In: Bella, P. (Ed.), "Research, Utilization and Protection of Caves", $6^{\text {th }}$ Scientific Conference with International Participation, Ždiar, 1.-5.10.2007, Liptovský Mikuláš. (in press) [In Czech with English abstract]

Orpurt P.A., 1964 - The microfungal flora of bat cave soils from Eleuthera Islands, The Bahamas. Canadian Journal of Botany. 42: 1629-1633.
Rutherford J.M. \& Huang L.H., 1994 - A study of fungi of remote sediments in West Virginia caves and a comparison with reported species in the literature. NSS Bulletin, 56: 3845.

Seigle-Murandi F., Nicot J., Sorin L. \& Genest L.Ch., 1980 - Association mycologique dans la Salle de la Verna et le tunnel de l'E.D.F. du réseau de la Pierre Saint Martin. Revue de Écologie et Biologie du Sol, 17: 149-157.

Sugita T., Kikuchi K., Makimura K., Urata K., Someya T., Kamei K., Niimi M. \& Uehara Y., 2005 - Trichosporon species isolated from guano samples obtained from bat-inhabited caves in Japan. Applied and Environmental Microbiology, 71: 7626-7629.

Šustr V., Elhottová D., Krištůfek V., Lukešová A., Nováková A., Tajovský K. \& Tříska J., 2005 - Ecophysiology of the cave isopod Mesoniscus graniger (Frivaldszky, 1865) (Crustacea: Isopoda). European Journal of Soil Biology, 41: 69-75.

Ulloa M., Lappe P., Aguilar S., Park H., Pérez-Mejia A., Toriello C. \& Taylor M.L., 2006 - Contribution to the study of the mycobiota present in the natural habitats of Histoplasma capsulatum: an integrative study in Guerrero, Mexico. Revista Mexicana de Biodiversidad, 77: 153-168.

Zeller L., 1962 - Gymnoascaceae from the Aggtelek cave "Baradla“ (Biospeleologica Hungarica, XVI.). Annales of the University of Sciences Budapest, Section Biology, 5: 273280.

Zeller L., 1966 - Keratinophilic fungi from the „Baradla“ cave in Aggtelek (Biospeleologica Hungarica, XXII.). Annales of the University of Sciences Budapest, Section Biology, 8: 375-388.

Zeller L., 1968a - Mucorales from the „Baradla“ cave in Aggtelek. (Biospeleologica Hungarica, XXII.). Annales of the University of Sciences Budapest, Section Biology, 9/10: 388-399.

Zeller L., 1968b - Chrysosporium species from the „Baradla“ cave in Aggtelek. (Biospeleologica Hungarica, XXIV.). Mycopathologia et Mycologia Applicata, 34: 296-301.

Zeller L., 1970 - Arthroderma species from the „Baradla“ cave in Aggtelek. (Biospeleologica Hungarica, XXII.). Annales of the University of Sciences Budapest, Section Biology, 12: 235-240. 